\title{
Application of Pont's Index to Lithuanian Individuals: a Pilot Study
}

\author{
Agneska Rykman ${ }^{1}$, Dalia Smailiene ${ }^{1}$ \\ ${ }^{1}$ Department of Orthodontics, Lithuanian University of Health Sciences, Lithuania.
}

\author{
Corresponding Author: \\ Agneska Rykman \\ LT-50153, Kacanausko 18-14, Kaunas \\ Lithuania \\ Phone: 0037063665640 \\ Fax: (352) 3739221 \\ E-mail: agnerykman@gmail.com
}

\section{ABSTRACT}

Objectives: A variety of diagnostic indices in orthodontics have been proposed to help in diagnosis and treatment planning. Pont's Index was established to predict ideal maxillary dental arch width from the sum of mesiodistal widths of four upper incisors. The aim of this study was to assess the applicability of Pont's Index to Lithuanian individuals.

Material and Methods: The sample comprised 52 subjects (age range from 18 to 35 years) with normal occlusion. Measurements were obtained directly from plaster casts using a digital calliper. Ideal arch widths were calculated for each subject according to Pont's formulae, and the correlation coefficients were calculated between the measured and the calculated arch width values.

Results: Correlation between the measured width values and the corresponding values calculated according to Pont's Index was moderate in all cases, with correlation coefficients values ranging from 0.59 (mandible) to 0.64 (maxilla) in first premolar's area and 0.49 in both maxilla and mandible in first molar's area $(\mathrm{P}<0.05)$. Appropriate index values for Lithuanian individuals were assessed to be 85.57 in premolars and 66.24 in molars area.

Conclusions: According to the results of this study, there was no strong evidence to suggest that Pont's Index could be reliably used to predict ideal arch width values in Lithuanian individuals.

Keywords: dental arch; mandible; maxilla; orthodontics.

\author{
Accepted for publication: 22 December 2015 \\ To cite this article: \\ Rykman A, Smailiene D. \\ Application of Pont's Index to Lithuanian Individuals: a Pilot Study \\ J Oral Maxillofac Res 2015;6(4):e4 \\ URL: http://www.ejomr.org/JOMR/archives/2015/4/e4/v6n4e4.pdf \\ doi: $10.5037 /$ jomr.2015.6404
}




\section{INTRODUCTION}

The understanding and analysis of dental arch dimensions is one of the fundamental bases in orthodontic diagnosis and treatment planning. Dental crowding and local irregularities can be solved with extraction or non-extraction approaches. Extra space may be created by teeth extraction, distalization of lateral teeth, interproximal dental stripping and dental arch expansion. Among non-extraction treatment methods arch expansion is one of the most commonly used. Stability of dental arch expansion has always been controversial [1]. In addition, the shape and width of dental arch is individual for each patient. Because of these reasons, Pont's Index [2] in 1909 has been proposed to guide clinicians in predicting the ideal arch width (hence the expansion) required to alleviate dental crowding and to produce more stable final results. Alberic Pont found that the constant relationship exists between the arch width and mesiodistal width of four maxillary incisors. Pont determined a constant ratio between the width of four upper incisors and the width of maxillary arch, measured between the centre of the occlusal surfaces of the first premolars (interpremolar width) and first molars (intermolar width). He suggested that the ratio of combined incisor's width to transverse arch width was ideally 0.8 in first premolars area, and 0.64 in first molars area.

Sum of the widths of

4 upper incisors (SIW)

0.8

ideal interpremolar arch width

(IPW)

Sum of the widths of

$\frac{4 \text { upper incisors (SIW) }}{0.64}=$ ideal intermolar arch width (IMW)

Pont did not indicate the size or selection criteria of his sample used to determine proposed Index, but did state that the test group was of French nationality only. He postulated that there were certain relationships between the form of the skull (brachycephalic, mesiocephalic, dolichocephalic) and the form of the dental arch, but Pont never elaborated further on this subject [2]. According to Alfred Cort Haddon [3] , the cephalic index of Lithuanians is 77 80, which means Lithuanians belong to mesiocephalic group. Pont suggested that Index should be applied to different ethnic groups for verification and correction. Some studies have shown that Pont's Index is a reliable tool to predict dental arch widths of subjects $[\underline{4}, \underline{5}]$, while other researchers claim the opposite $[\underline{6}, \underline{7}]$.
Therefore, the present study was initiated to assess the applicability of Pont's Index to mesiocephalic Lithuanian individuals.

The null hypothesis tested: Pont's Index could be reliably used to predict the ideal arch width values in Lithuanian individuals.

\section{MATERIAL AND METHODS Collection of data}

Dental casts were taken from 52 subjects ( 32 females and 20 males; age 25.19 [4.45] years, range from 18 to 35 years) that were selected among the students from Twin Study in Department of Orthodontics, Lithuanian University of Health Sciences.

This study was conducted from December 15, 2014 to March 15, 2015.

\section{Inclusion criteria}

Inclusion criteria were as follows:

1. Lithuanian nationality (mesiocephalic);

2. permanent dentition;

3. all teeth present, except third molars;

4. occlusion corresponded Andrew's 6 keys to normal occlusion;

5. normal overjet $(1-4 \mathrm{~mm})$ and overbite $(1-4 \mathrm{~mm})$;

6. no visible restorations;

7. no history of any kind of orthopedic or orthodontic treatment;

8. no anomalies in teeth form, number, alignment.

\section{Measurements}

Measurements were obtained directly from plaster casts using a digital calliper GARANT (Garant; Hoffmann, München, Germany) with rod type depth gauge and data output (accuracy $0.01 \mathrm{~mm}$ ). Measurements included sum of mesiodistal crown diameters of the four maxillary incisors (SIW); interpremolar and intermolar maxillary and mandible dental arch widths as specified by Pont [8]. The landmarks used for measurements were as follows (Figure 1):

Maxillary:

- interpremolar width (IPW): distance between central grooves on the occlusal surface of first premolars;

- intermolar (IMW): distance between mesial pits on the occlusal surface of first molars;

Mandible:

- interpremolar width (IPW): distance between contact points between first and second premolars; 


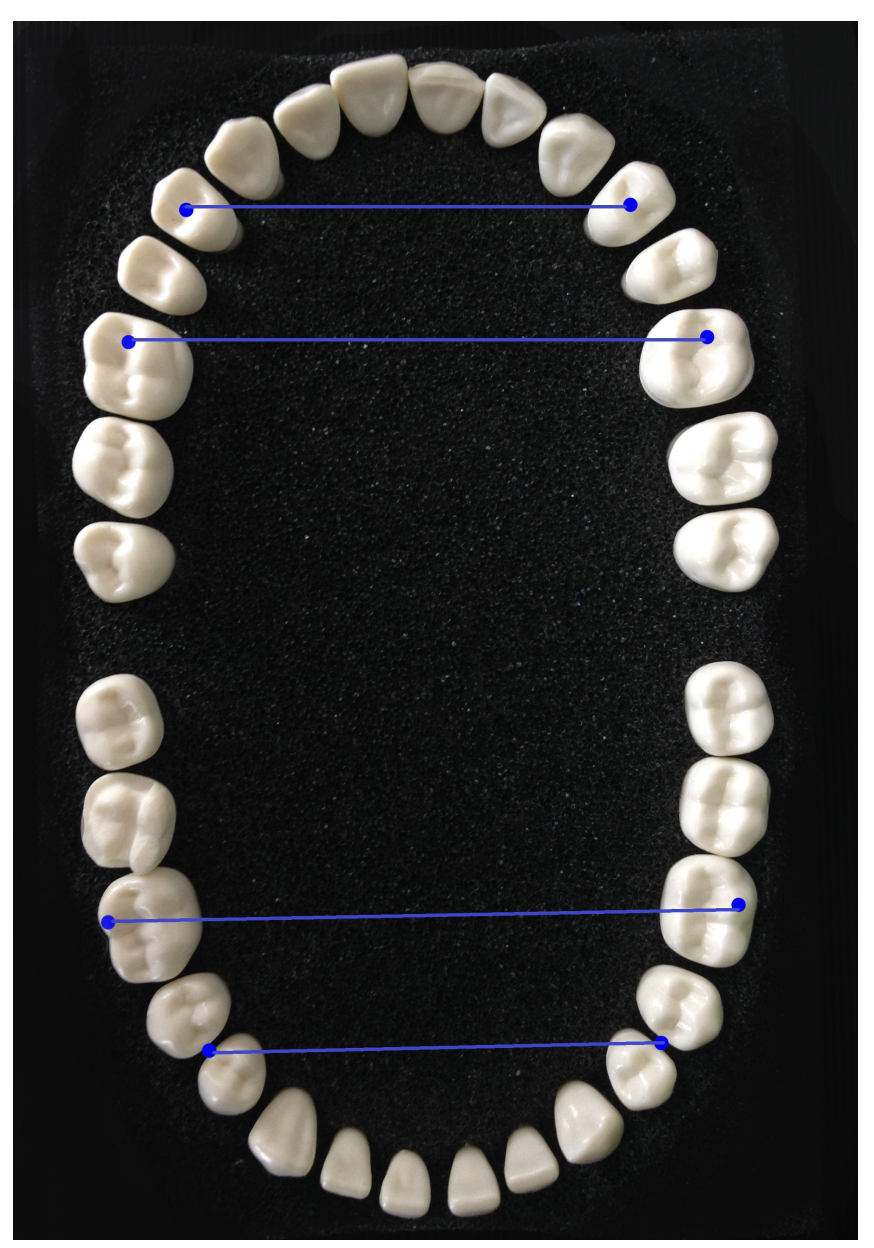

Figure 1. Landmarks used for measurements in maxillae (on top) and mandible (on bottom).

- intermolar (IMW): distance between tips of distobuccal cusps of first molars.

\section{Error of the method}

To determine the errors associated with cast measurements, 15 cast models were randomly selected and measurements were repeated by the same observer 2 weeks after. The mean errors calculated using Dahlberg's formula ranged from $0.09 \mathrm{~mm}$ to $0.16 \mathrm{~mm}$ for tooth width and from $0.13 \mathrm{~mm}$ to 0.47 $\mathrm{mm}$ for arch width measurements. These findings indicated that experimental errors were generally small and unlikely to bias the results.

\section{Statistical analysis}

All statistical analyses were performed using the Statistical Package of Social Sciences (Windows, Version 16.0, SPSS Inc., Chicago, Illinois, USA). The statistical method used was Student's two-tailed test and Pearson analysis.

Incisor and arch widths were recorded for each subject to the nearest $0.01 \mathrm{~mm}$ and described in terms of mean and standard deviation (M [SD]). Arch widths were calculated for each subject according to Pont's formulae, and the correlation and determination coefficients were calculated between the measured and the calculated arch width values. Statistical significance level was defined at $\mathrm{P} \leq 0.05$.

\section{RESULTS}

The mean values of measured and calculated arch widths are presented in Table 1. Calculated values were statistically significantly bigger than measured values.

Correlation between measured and calculated dental arch widths were moderate in all cases, with coefficient of correlation (r) ranging from 0.49 to 0.64 (Table 2). Values of coefficient of determination $\left(\mathrm{r}^{2}\right)$, indicating how well data fit a statistical model, ranged from 0.24 to 0.41 (Table 2).

Most of observed arch width values were under Pont's prediction, which means that Pont's Index overestimated values in Lithuanian dental arch widths. Measured arch widths were wider than expected from $6 \%$ (mandible interpremolar) to $31 \%$ (mandible intermolar) of cases. Percentage of cases, that matched $\pm 1 \mathrm{~mm}$ around Pont's prediction ranged from $11.5 \%$ (mandible interpremolar) to $34.6 \%$ (mandible intermolar).

Table 1. Upper incisor widths (SIW) and arch width values (in mm) described in terms of arithmetic means and standard deviations (SD)

\begin{tabular}{c|c|c|c|c|c}
\hline \multirow{2}{*}{ Variables } & Measured & \multicolumn{2}{c|}{ Calculated } & \multirow{2}{*}{ P } \\
\cline { 2 - 5 } & Mean & SD & Mean & SD & \\
\hline SIW & 30.52 & 1.86 & - & - & - \\
\hline \multicolumn{6}{c}{ Arch widths } \\
\hline $4-4$ & 35.66 & 2.36 & 38.15 & 2.32 & 0.000 \\
\hline $6-6$ & 46.07 & 2.67 & 47.71 & 2.88 & 0.000 \\
\hline \multicolumn{7}{c}{ Mandible } \\
\hline $4-4$ & 34.51 & 2.57 & 38.15 & 2.32 & 0.000 \\
\hline $6-6$ & 46.78 & 3.15 & 47.71 & 2.88 & 0.031 \\
\hline
\end{tabular}

Table 2. Pearson correlation coefficient (r) and coefficients of determination $\left(\mathrm{r}^{2}\right)$ between measured and calculated arch width values according to Pont's formula

\begin{tabular}{l|c|c|c}
\hline \multirow{2}{*}{\multicolumn{1}{c|}{ Arch widths }} & \multicolumn{3}{c}{ Sample (n=52) } \\
\cline { 2 - 4 } & $\mathbf{r}$ & $\mathbf{r}^{2}$ & $\mathbf{P}$ \\
\hline Maxillae interpremolar & 0.64 & 0.41 & $\leq 0.05$ \\
\hline Maxillae intermolar & 0.49 & 0.24 & $\leq 0.05$ \\
\hline Mandible interpremolar & 0.59 & 0.35 & $\leq 0.05$ \\
\hline Mandible intermolar & 0.49 & 0.24 & $\leq 0.05$ \\
\hline
\end{tabular}


The largest difference under Pont's prediction was ascertained in mandible interpremolar area $(-9.41 \mathrm{~mm})$, whilst largest difference over Pont's prediction was ascertained in mandible intermolar area $(7.04 \mathrm{~mm})$. The differences between measured and calculated arch width values were calculated for each individual subject and are presented in Figure 2.

In present study, we decided to find out which values of Index would be appropriate for mesiocephalic Lithuanian individuals. As better correlation was found in maxillae, values were calculated according to the measurements of upper jaw (with a width of two standard deviations). The appropriate values of Pont's Index for mesiocephalic Lithuanian population was ascertained to be 85.57 in premolar area and 66.24 in molar area.

\section{DISCUSSION}

Pont's Index has been proposed to predict ideal dental arch width. This method has gained resurgence in interest [9]. The applicability of Index has been assessed in many investigations of different ethnic origins to determine whether the Index could be applied to different populations (Table 3). No study before has been undertaken to assess Pont's Index on Lithuanian or any population of Baltic States.

The results of present study showed moderate correlation between Pont's predicted widths and real sizes of dental arches in Lithuanian population. In contrast, other researchers have found lower correlation and have denied use of Index as a reliable diagnostic tool in orthodontics. Al-Omari et al. [6] in a recent study reported low $(r=0.25$ to $0.39)$ correlation between calculated and measured dental arch widths in Jordanians. In addition, Hong et al. [10], in their study on Nepalese population, have found very low correlation $(\mathrm{r}=0.07$ to 0.29). On the other hand, studies, approving use of Pont's Index are present as well. Significant correlation between Pont's suggested dental arch widths and measured values was ascertained in Sridharan's research on Tumkur population [11].

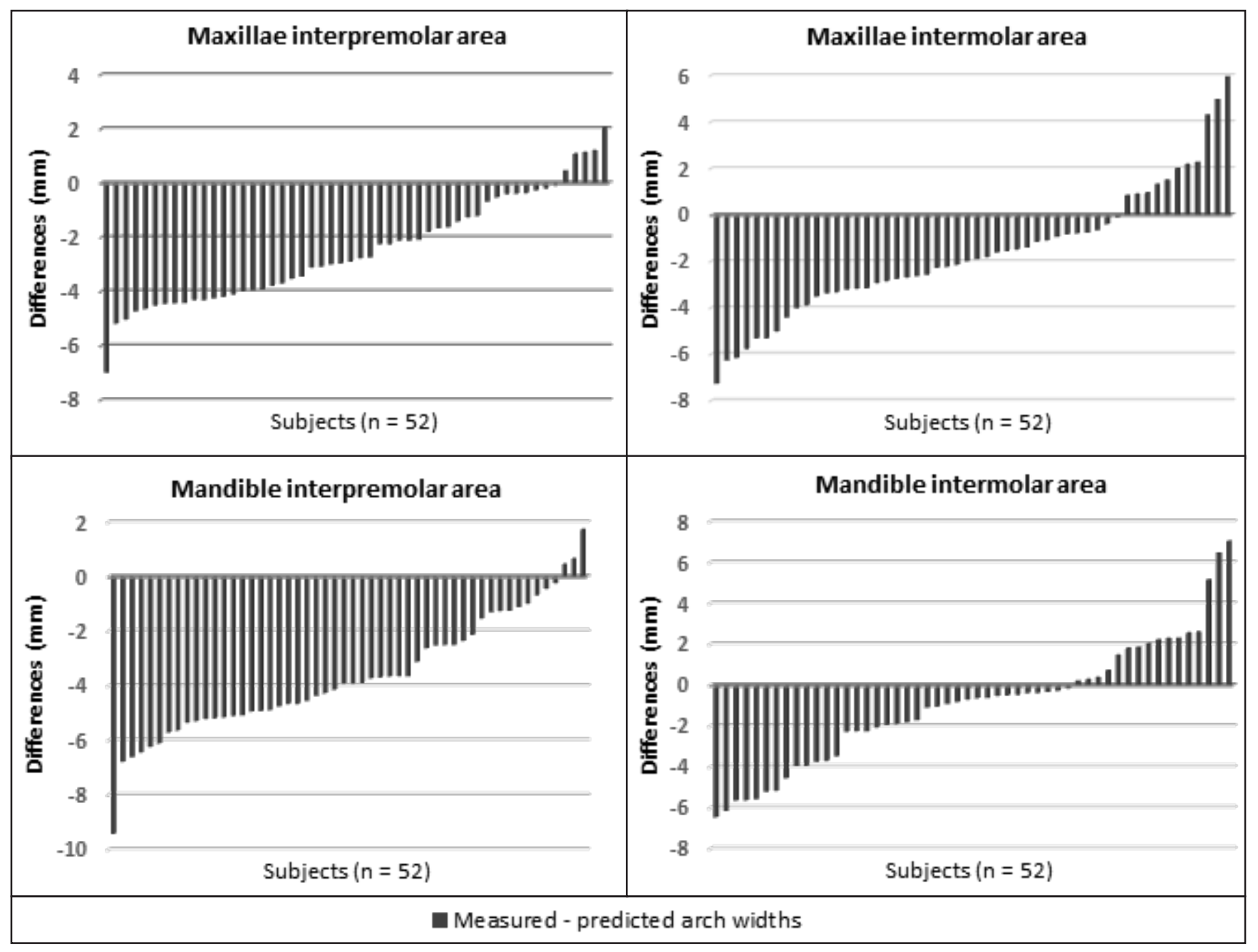

Figure 2. Differences between measured and predicted arch width values in millimetres (negative values - under Pont's prediction; positive - over Pont's prediction). 
Table 3. Studies on the applicability of Pont's Index

\begin{tabular}{|c|c|c|c|c|}
\hline Study & $\begin{array}{c}\text { Sample } \\
\text { size }\end{array}$ & Population & Results & Approval \\
\hline $\begin{array}{l}\text { Joondeph } \\
\text { et al. [2] }\end{array}$ & 20 & - & $\begin{array}{l}\text { Correlation coefficients between measured and predicted according to Pont dental } \\
\text { arch widths were low. }\end{array}$ & $\begin{array}{c}\text { Disapproved } \\
\text { (underestimation) }\end{array}$ \\
\hline $\begin{array}{l}\text { Gupta et al. } \\
{[\underline{4}]}\end{array}$ & 100 & $\begin{array}{l}\text { North } \\
\text { Indian }\end{array}$ & $\begin{array}{l}\text { Significant correlations were found to exist between combined maxillary incisor } \\
\text { widths and the maxillary interpremolar and intermolar arch widths. Suggested val- } \\
\text { ues of Index: } 81.66 \text { for premolars and } 65.44 \text { for molars. }\end{array}$ & $\begin{array}{c}\text { Approved } \\
\text { (with different } \\
\text { values of Index) }\end{array}$ \\
\hline Stifter $[\underline{5}]$ & 57 & $\begin{array}{l}\text { Navaho } \\
\text { Indians }\end{array}$ & $\begin{array}{l}\text { In the group of subjects with ideal occlusion significant correlation existed between } \\
\text { the combined incisor widths and the molar and upper premolar widths. No cor- } \\
\text { responding correlation could be found in the subjects with normal occlusion. The } \\
\text { lower premolar width had no significant correlation to incisor width in both groups. }\end{array}$ & Approved \\
\hline $\begin{array}{l}\text { Al-Omari } \\
\text { et al. [ }[\underline{]}\end{array}$ & 144 & Jordanian & $\begin{array}{l}\text { Correlation coefficients were low in all cases (with } r \text { values ranging from } 0.25 \text { to } \\
0.39 \text { ). }\end{array}$ & $\begin{array}{c}\text { Disapproved } \\
\text { (overestimation) }\end{array}$ \\
\hline $\begin{array}{l}\text { Hong et al. } \\
{[\underline{10}]}\end{array}$ & 100 & Nepalese & $\begin{array}{l}\text { Correlation coefficients were very low in all cases (with } \mathrm{r} \text { values ranging from } 0.07 \\
\text { to } 0.29 \text { ). }\end{array}$ & $\begin{array}{c}\text { Disapproved } \\
\text { (overestimation) }\end{array}$ \\
\hline $\begin{array}{l}\text { Sridharan } \\
{[11]}\end{array}$ & 62 & Tumkur & $\begin{array}{l}\text { Correlation coefficients were statistically significant. It was concluded that Pont's } \\
\text { Index can be applied in Tumkur population. }\end{array}$ & Approved \\
\hline $\begin{array}{l}\text { Nimkarn } \\
\text { et al. [12] }\end{array}$ & 40 & Caucasians & $\begin{array}{l}\text { Interpremolar widths were more strongly correlated than intermolar widths. Pont's } \\
\text { Index overestimated the interpremolar and intermolar arch widths by } 4.7 \text { and } 2.5 \\
\text { mm respectively. }\end{array}$ & $\begin{array}{c}\text { Disapproved } \\
\text { (overestimation) }\end{array}$ \\
\hline $\begin{array}{l}\text { Ordoubazary } \\
\text { et al. }[\underline{13}]\end{array}$ & 80 & Iranian & $\begin{array}{l}\text { There was a statistically significant difference between predicted and calculated } \\
\text { dental arch widths. }\end{array}$ & $\begin{array}{c}\text { Disapproved } \\
\text { (overestimation) }\end{array}$ \\
\hline $\begin{array}{l}\text { Thu et al. } \\
\text { [14] }\end{array}$ & 85 & Malay & Predicted dental arch measurements were significantly greater than measured ones. & $\begin{array}{c}\text { Disapproved } \\
\text { (overestimation) }\end{array}$ \\
\hline
\end{tabular}

Stifter et al. [ $\underline{5}$ ] ascertained a significant correlation in Navaho Indian population having ideal occlusion. Gupta et al. [4] evaluated dental casts of 100 Northern Indians and proposed different Index values (81.66 for premolars and 65.44 for molars). The values of Index, proposed by Gupta are bigger than the original ones (80 and 64 respectively). However, our calculated values are even bigger, especially for a premolar region (85.57 for premolar area and 66.24 for molar area). Although some inaccuracies of these values are possible taking into consideration small sample size and high variance of measured values.

In our study some subjects were "over Pont's prediction", which means that their observed arch widths were larger than those predicted ones. On the other hand, some subjects were "under Pont's prediction" indicating that their observed arch widths were less than expected according to Pont's Index. These results demonstrate individuality of dental arch sizes in Lithuanian subjects. As seen from the results, the majority of observed measurements were significantly less than calculated values, which means that Pont's Index in general overestimates the dental arch widths values in Lithuanian individuals. This is in agreement with results of other studies, where overestimation of values were found [6,10,12-14]. Nimkarn et al. [12] found that Pont's Index overestimated interpremolar arch width by $4.7 \mathrm{~mm}$ and intermolar arch width by $2.5 \mathrm{~mm}$.
To compare, in our study, upper interpremolar arch width was overestimated in average by $2.49 \mathrm{~mm}$, lower interpremolar arch width - by $3.64 \mathrm{~mm}$, upper intermolar arch width - by $1.64 \mathrm{~mm}$ and lower intermolar arch width - by $0.93 \mathrm{~mm}$.

The highest percentage of individuals having an observed arch width values $\pm 1 \mathrm{~mm}$ around Pont's prediction was observed in mandible intermolar area, although it was only $34.6 \%$. Consequently we can say that the null hypothesis was rejected: Pont's Index cannot provide reliable predictions for individual orthodontic treatment planning for Lithuanian individuals.

\section{CONCLUSIONS}

According to the results of this study, there was no strong evidence to suggest that Pont's Index could be reliably used to predict the ideal arch width values for mesiocephalic Lithuanian individuals. Further investigations are needed.

\section{ACKNOWLEDGMENTS AND DISCLOSURE STATEMENTS}

The authors report no conflicts of interest related to this study. 


\section{REFERENCES}

1. Housley JA, Nanda RS, Currier GF, McCune DE. Stability of transverse expansion in the mandibular arch. Am J Orthod Dentofacial Orthop. 2003 Sep; 124(3):288-93. [Medline: 12970662] [doi: 10.1016/S0889-5406(03)00450-5]

2. Joondeph DR, Riedel RA, Moore AW. Pont's Index: A Clinical Evaluation. The Angle Orthod. 1970 Apr; 40(2):112-18. [Medline: 5266011] [doi: 10.2319/0003-3219(2007)077[0237:LSOUPC]2.0.CO;2]

3. Haddon AC. The Races of man and their distribution. 1st ed. Cambridge: Cambridge University Press; 1924. p. 44.

4. Gupta DS, Sharma VP, Aggarwal SP. Pont's Index as applied on Indians. Angle Orthod. 1979 Oct; 49(4):269-71. [Medline: 292350]

5. Stifter J. A study of Pont's, Howe's, Ree's, Neff's and Bolton analyses on Class I adult dentitions. Angle Orthod 1958 Oct; 28(4):215-25. [doi: 10.1043/0003-3219(1958)0282.0.CO]

6. Al-Omari IK, Duaibis RB, Al-Bitar ZB. Application of Pont's Index to a Jordanian population. Eur J Orthod. 2007 Dec; 29(6): 627-31. [Medline: 17971353] [doi: 10.1093/ejo/cjm067]

7. Celebi AA, Tan E, Gelgor IE. Determination and application of Pont's Index in Turkish population. ScientificWorldJournal. 2012;2012:494623. [Medline: 22654616] [PMC free article: 3361250] [doi: 10.1100/2012/494623]

8. Harzer W. [Lehrbuch der Kieferorthopädie]. München, Hanser. 1999. p. 119.

9. Purmal K, Alam MK, Cheong NW. Pont's Index Is Not Exact Science: A Reappraisal. Int Med J 2013 Apr; 20 (2): $204-7$.

10. Hong Q, Tan J, Koirala R, Lina Y, Shimizu T, Nakano K, Kishimoto E, Takamata T, Okafuji N. A study of Bolton's and Pont's analysis on permanent dentition of Nepalese. J Hard Tissue Biol 2008 Oct; 17(2): 55-62. [doi: $10.2485 / \mathrm{jhtb} .17 .55]$

11. Sridharan K. Evaluation of validity of Pont's analysis in Tumkur population. J Dental Sci Res 2011: 41-9.

12. Nimkarn Y, Miles PG, O’Reilly MT, Weyant RJ. The validity of maxillary expansion indices. Angle Orthod 1995; 65(5): 321-326. [Medline: $\underline{8526290}$ ]

13. Ordoubazary M, Zafarmand AH, Madani A, Ordoubazary A. Comparison of Pont's and Korkhaus indices at different populations. Ellenike Orthod Epitheorese 2007; 10(2): 67-74.

14. Thu KM, Winn T, Abdullah N, Jayasinghe JA, Chandima GL. The maxillary arch and its relationship to cephalometric landmarks of selected Malay ethnic group. MJMS 2005 Jan; 12(1): 29- 38. [Medline: 22605945] [PMC free article: 3349411]

\section{To cite this article:}

Rykman A, Smailiene D.

Application of Pont's Index to Lithuanian Individuals: a Pilot Study

J Oral Maxillofac Res 2015;6(4):e4

URL: http://www.ejomr.org/JOMR/archives/2015/4/e4/v6n4e4.pdf

doi: $10.5037 /$ jomr.2015.6404

Copyright (C) Rykman A, Smailiene D. Published in the JOURNAL OF ORAL \& MAXILLOFACIAL RESEARCH (http://www.ejomr.org), 31 December 2015.

This is an open-access article, first published in the JOURNAL OF ORAL \& MAXILLOFACIAL RESEARCH, distributed under the terms of the Creative Commons Attribution-Noncommercial-No Derivative Works 3.0 Unported License, which permits unrestricted non-commercial use, distribution, and reproduction in any medium, provided the original work and is properly cited. The copyright, license information and link to the original publication on (http://www.ejomr.org) must be included. 